\title{
GLOSA DO WYROKU SĄDU OKRĘGOWEGO W JELENIEJ GÓRZE Z DNIA 26 LIPCA 2013 R., VI KA 307/13
}

\begin{abstract}
Streszczenie. Przedmiotem komentowanej glosy są zagadnienia związane z przestępstwem utrwalenia nagiego wizerunku. Ponadto została poruszona kwestia możliwości jego rozpoznawalności w przypadku, gdy dane nie zostały zapisane na nośniku informacji. Podjęto również problem odtwarzania wizerunku ze względu na realizację znamienia „utrwalenia wizerunku”. Co więcej, autor podjął się analizy znaczenia prawa do intymności na gruncie art. 191a k.k. Dodatkowo zostały omówione znamiona „przemocy” oraz „groźby” z uwagi na rodzaj środków, którymi posługuje się sprawca do dokonania tego czynu. Na koniec dokonano oceny zakwalifikowania wspomnianego czynu jako usiłowanie przestępstwa.
\end{abstract}

Słowa kluczowe: utrwalanie wizerunku, nagi wizerunek, przestępstwo przeciwko wolności, prawo do intymności, usiłowanie utrwalenia nagiego wizerunku.

\section{STAN FAKTYCZNY}

Komentowany wyrok dotyczy popełnienia przez sprawcę kilku czynów zabronionych, w tym również realizacji znamion przestępstwa utrwalenia nagiego wizerunku, ujętego w art. 191a ustawy z dnia 6 czerwca 1997 r. - Kodeks karny (Dz. U. 1997, Nr 88, poz. 553 ze zm., dalej: k.k.). Wraz z natężeniem procesu technologizacji oraz rozwojem dostępu do sieci teleinformatycznej, problem dysponowania nagim wizerunkiem staje się coraz powszechniejszy. Z uwagi na postępującą świadomość społeczną w zakresie prawa do poszanowania godności ludzkiej oraz prawa do prywatności, należy spodziewać się, iż w gestii sądów coraz częściej będzie pozostawała ocena w przedmiocie dokonania czynu przewidzianego art. 191a k.k. Z tej przyczyny wydaje się niezmiernie istotną kwestią, aby ustalić zakres znaczeniowy pojęć będących składowymi poszczególnych znamion tego przestępstwa. Na gruncie glosy zostanie podjęta próba oceny wniosków przyjętych przez sąd, w odniesieniu do wspomnianego przestępstwa ${ }^{1}$.

* Uniwersytet Łódzki, Wydział Prawa i Administracji, Katedra Prawa Karnego Międzynarodowego, Zakład Międzynarodowego Wymiaru Sprawiedliwości, k.witczak1@wp.pl.

${ }^{1}$ Ze względu na zawężony charakter niniejszego opracowania stan faktyczny sprawy, zarzuty podniesione przez obrońcę oskarżonego oraz wyroki Sądu Rejonowego i Sądu Okręgowego zostaną przedstawione w ograniczonym stopniu, umożliwiającym zaprezentowanie zagadnienia z art. 191a k.k. 
Sąd Rejonowy w Jeleniej Górze rozpatrywał następujący stan faktyczny: między 1 września a 6 grudnia 2010 r. oskarżony M. P. wspólnie, w porozumieniu z inną osobą czerpali korzyści majątkowe w wyniku uprawiania prostytucji przez pokrzywdzoną V. W. Mężczyźni uczynili sobie z tego procederu źródło stałego dochodu. Należy nadmienić, iż M. P. dopuścił się podobnego przestępstwa w warunkach recydywy i został skazany w 2005 r. na karę łączną 6 lat i 6 miesięcy pozbawienia wolności za czyny z art. $158 \S 3$ k.k. w zW. z art. $64 \S 1$ k.k. oraz art. $278 \S 1$ k.k. w zw. z art. $64 \S 1$ k.k., a także w 2008 r. za przestępstwa podobne za czyny z art. 59 ust. 1 ustawy z dnia 29 lipca 2005 r. o przeciwdziałaniu narkomanii (Dz. U. 2005, Nr 179, poz. 1485 ze zm.), w zw. z art. 12 k.k. w zw. z art. 64 $\S 1$ k.k. na karę 3 lat pozbawienia wolności, następnie objętymi wyrokiem łącznym na karę łączną 8 lat pozbawienia wolności.

Następnie od 6 do 8 grudnia 2010 r. oskarżony używał wobec V. W. przemocy oraz gróźb bezprawnych. W następstwie zmuszał pokrzywdzoną do określonego zachowania, pozbawił ją wolności, wywierał wpływ na jej zeznania jako świadka. Usiłował również zmusić ją do uprawiania prostytucji. Zachowanie sprawcy wobec ofiary przybrało postać uderzenia pięścią w twarz oraz kopania po całym ciele. W dodatku M. P. zmusił pokrzywdzoną do rozebrania się i zgolenia maszynką do golenia włosów z części głowy. W dalszej kolejności kilka razy zanurzył jej głowę w muszli klozetowej, po czym nakazał napisanie listu pożegnalnego do matki. Co więcej, V. W. została zmuszona do rozebrania się. M. P. przy wykorzystaniu aparatu cyfrowego utrwalił jej nagi wizerunek. Poza tym oskarżony za pośrednictwem telefonu kilkakrotnie groził pozbawieniem życia oraz uszkodzeniem ciała matki pokrzywdzonej, a nadto żądając od niej kwoty 2500 zł. W ten sposób usiłował doprowadzić V. W. do uprawiania prostytucji, przy czym zamierzonego celu nie osiągnął z uwagi na odmowę.

Opisane czynności miały na celu uniemożliwienie złożenia zawiadomienia o przestępstwie i zeznań w charakterze świadka na okoliczności: przemocy stosowanej wobec innej osoby, obrotu narkotykami oraz udziału w pobiciu. Należy przy tym dodać, iż przywołane groźby wywołały u pokrzywdzonej uzasadnioną obawę ich spełnienia.

Sąd Rejonowy uznał M. P. za winnego popełnienia wyżej wymienionych czynów i zdecydował o połączeniu orzeczonych kar, a w konsekwencji o wymierzeniu kary łącznej na podstawie art. 85 k.k. i art. 86 k.k. Wynosiła ona 3 lata pozbawienia wolności.

Apelację od tego rozstrzygnięcia wniósł obrońca M. P., który zaskarżył orzeczenie w całości na podstawie art. 444 k.p.k. ustawy z dnia 6 czerwca 1997 r. - Kodeks postępowania karnego (Dz. U. 1997, Nr 89, poz. 555 ze zm.) oraz $445 \S 1$ k.p.k. i 447 § 1 k.p.k. Powyższemu wyrokowi zarzucił m.in. ${ }^{2}$, iż opinia biegłego

${ }^{2}$ Ze względu na ograniczenia objętościowe, a także cel glosy oraz charakter poruszanego w niej problemu zostaną przytoczone jedynie wybrane zarzuty obrońcy. 
z zakresu informatyki jednoznacznie neguje ustalenie poczynione przez sąd, jakoby M. P. nakazał kobiecie rozebranie do naga, po czym wykonał jej zdjęcie. Treść wspomnianej opinii wskazuje, iż w momencie zatrzymania w zabezpieczonym aparacie fotograficznym nie znajdowały się zdjęcia przedstawiające nagi wizerunek pokrzywdzonej. Co więcej, tego typu fotografie nie zostały również skasowane $\mathrm{z}$ urządzenia po ich wykonaniu.

W związku z przedstawionymi zarzutami obrońca wniósł o uchylenie zaskarżonego wyroku i przekazanie sprawy sądowi I instancji do ponownego rozpoznania, ewentualnie w zakresie zarzutu dotyczącego rażącej niewspółmierności kary, na podstawie przepisów art. 427 § 1 k.p.k. oraz 437 § 1 k.p.k., wniósł o zmianę zaskarżonego wyroku poprzez wymierzenie kary z warunkowym zawieszeniem jej wykonania.

Sąd Okręgowy w Jeleniej Górze w uzasadnieniu do wyroku z dnia 26 lipca 2013 r. jako determinanty dla oceny jego charakteru (VI Ka 307/13) podzielił pogląd Sądu Rejonowego co do oceny dowodów. Otóż, sam oskarżony twierdził, iż robił V. W. zdjęcia po tym, jak ją uderzył. Mężczyzna wskazuje jedynie na odmienny charakter fotografii, aniżeli wynika to z zeznań pokrzywdzonej. Nie można poczytywać w kategorii argumentu na potwierdzenie tezy, że zdjęcia nie były wykonywane, faktu, iż biegły w aparacie oskarżonego nie ujawnił zdjęć ani nakręconego filmu, prezentujących nagi wizerunek pokrzywdzonej. Oskarżony twierdził bowiem, że materiały te $\mathrm{z}$ aparatu usunął. Wobec treści wyjaśnień oskarżonego nie można też rozstrzygnąć, czy wykonane zdjęcia i film zostały zapisane w pamięci aparatu, czy jedynie na jego zewnętrznej karcie pamięci, którą oskarżony mógł łatwo usunąć, nie pozostawiając śladu w aparacie. Jednakże w tym stanie faktycznym pozostaje to bez znaczenia, skoro sam oskarżony przyznaje, że zdjęcia pokrzywdzonej wykonywał.

Sąd wyższej instancji postanowił o utrzymaniu w tym fragmencie zaskarżonego wyroku w mocy.

\section{OCENA PRAWNA WYROKU SĄDU OKRĘGOWEGO W JELENIEJ GÓRZE Z DNIA 26 LIPCA 2013 R., VI KA 307/13}

$\mathrm{Na}$ wstępie na aprobatę zasługuje zakwalifikowanie czynu oraz okoliczności jemu towarzyszących jako potencjalnie wypełniające zespół znamion uwzględnionych w art. 191a k.k. Z uzasadnienia do ustawy z 5 listopada 2009 r. (Dz. U. 2009, Nr 206, poz. 1589) wynika, iż jako motyw dla wprowadzenia tego przepisu projektodawca wskazał dotychczasowy brak ochrony przed nadużyciem zaufania przez jednego z partnerów podczas kontaktów seksualnych. Uściślając, chodziło o sytuacje, gdy jeden z uczestników czynności o charakterze erotycznym potajemnie utrwala jej przebieg lub obraz nagiego ciała innej osoby (Druk sejmowy nr 1394). Ponadto w tym samym dokumencie został przywołany przykład, iż w jednej z łódzkich prokuratur rejonowych toczyło się postępowanie na skutek 
zawiadomienia złożonego przez kobietę, ponieważ mężczyzna, z którym pozostawała w związku, utrwalił potajemnie przebieg odbywanych z nią stosunków seksualnych. Po rozpadzie wspomnianej relacji zmontował z powstałych zapisów obrazów film z rozpoznawalnym wizerunkiem pokrzywdzonej. Następnie upowszechnił go w Internecie, uprzednio informując o tym fakcie oraz miejscu udostępnienia nagrania, grono znajomych kobiety (Druk sejmowy nr 1394).

Odmiennie aniżeli w przykładzie przywołanym powyżej, w omawianym stanie faktycznym nie zachodzą relacje partnerskie między M. P. a pokrzywdzoną. Jednakże w obu przypadkach czynności zostały podjęte celem osiągnięcia takiego samego rezultatu. Mianowicie, obaj mężczyźni dążyli do tego, aby kobiety odczuły skutki o infamującym charakterze. Jeden z nich dopuścił się czynu, jak można przypuszczać, kierując się chęcią zemsty na partnerce po rozpadzie ich związku. Natomiast drugi, zmuszając przemocą pokrzywdzoną do „pozowania”, potraktował utrwalony nagi wizerunek V. W. jako „zabezpieczenie” przed niekorzystnym dla niego złożeniem zeznań, gdyż występowała ona w postępowaniu w roli świadka. Zarówno w jednej, jak i drugiej sytuacji powzięte działania miały na celu wywołanie uczucia wstydu lub powstania obawy przed wywołaniem tego uczucia ${ }^{3} \mathrm{w}$ następstwie upublicznienia szczegółów dotyczących życia intymnego bądź nagiego wizerunku, który również należy poczytać jako jeden z elementów związanych ze sferą intymną człowieka.

O trafności zaklasyfikowania czynu dokonanego przez oskarżonego jako przestępstwa objętego art. 191a k.k. przesądza również charakter dobra chronionego tą regulacją prawną. J. Lachowski podnosi, iż w tym przypadku jako przedmiot ochrony należy poczytać wolność człowieka w ramach dysponowania własnym wizerunkiem w związku z intymną sferą życia (Lachowski 2016, 872). Ponadto ta regulacja służy chronieniu prywatności, wolności od obawy przed ujawnieniem faktów z życia intymnego (tamże). Z kolei wedle M. Filara oraz M. Berenta przedmiot ochrony z art. 191a k.k. przyjmuje postać wolności decyzyjnej człowieka w obszarze intymności połączonej ze sferą jego seksualizmu (Filar 2014, 1187-1188). Jej spektrum obejmuje również prawo do intymności w związku z eksponowaniem utrwalonych jej przejawów na zewnątrz (tamże). Natomiast M. Mozgawa zwraca uwagę, iż trudno zrozumieć pobudki, jakimi kierował się ustawodawca, nie dokonując umiejscowienia tego przepisu w rozdziale XXV k.k. „Przestępstwa przeciwko wolności seksualnej i obyczajności”, bowiem zdaniem przedstawiciela doktryny $\mathrm{w}$ tym przypadku dobrem chronionym jest obyczajność, choć przede wszystkim intymność oraz prywatność człowieka (Mozgawa 2017, 582). Za to $\mathrm{S}$. Hypś uważa, iż w ramach przedmiotu karnoprawnej ochrony, wynikającej z omawianej regulacji, można wyróżnić wolność decydowania o utrwalaniu i rozpowszechnianiu własnego wizerunku w stanie nagości lub w trakcie czynności seksualnych (Hypś 2017, 922). W zakresie ochrony mieści się także

\footnotetext{
${ }^{3}$ Tego typu pobudka towarzyszyła działaniu sprawcy z glosowanego orzeczenia.
} 
prawo do życia prywatnego, ponieważ naruszana tym czynem sfera intymna osoby pokrzywdzonej stanowi ważny składnik owego prawa (tamże). W końcu J. Kosonoga twierdzi, że dobra chronionego należy upatrywać w swobodzie jednostki do dysponowania własnym intymnym wizerunkiem, czyli takim, który ukazuje nagą osobę lub podczas czynności seksualnej (Kosonoga 2017, 1139).

W każdym z przytoczonych poglądów prezentowanych przez przedstawicieli doktryny prawa karnego zostaje poruszone zagadnienie ludzkiej intymności. W powyższych wypowiedziach przybiera ono różne formy, chociażby w postaci nawiązania do sfery intymnej człowieka jako składnika prawa do prywatności, wyodrębnionego od pozostałych części składowych, lecz jednocześnie integralnego przymiotu człowieka. Ponadto intymność może stanowić również indywidualny przedmiot ochrony, wywodzący się z regulacji z art. 191a k.k. Bez względu, na to, którą koncepcję przyjmiemy za właściwą, w każdej z nich jest zaznaczona bezpośrednio lub pośrednio potrzeba ochrony intymności.

Odnosząc poprzednie stwierdzenie do stanu faktycznego ujętego w analizowanym orzeczeniu, należy stwierdzić, iż w działaniu oskarżonego, które podjął wobec pokrzywdzonej celem utrwalenia jej nagiego wizerunku, nie należy dopatrywać się przejawów seksualizacji zachowania, co miałoby miejsce w przypadku czynu z art. $202 \S 3$ k.k. Natomiast podjęte przez sprawcę czynności świadczą o jego woli przełamania strefy komfortu związanej z intymnością ofiary oraz wywołania obawy przed ewentualną publikacją utrwalonych fotografii. O podłożu dokonanych przez niego działań dowodzi również brutalizacja postawy, która uzewnętrzniała się w stosowanej przemocy - zgoleniu głowy, kopaniu - wobec V. W. Czynności dokonane przez oskarżonego miały przyczynić się do przełamania oporu psychicznego kobiety.

Należy zaznaczyć, iż w art. 191a k.k. ustawodawca przewidział dwa alternatywne rodzaje czynności sprawczej: utrwalanie wizerunku lub jego rozpowszechnianie. Jednakże, ze względu na stan faktyczny analizowanej sprawy, zostanie omówiona jedynie pierwsza postać z wymienionych. Dlatego, przechodząc do analizy działań podjętych przez M. P., należy uprzednio przytoczyć definicję słownikową pojęcia „utrwalać”. Wspomniany termin należy poczytywać jako „[...] uczynić trwałym, trwalszym, oprzeć na trwałej podstawie, utwierdzić, umocnić, ugruntować" (Dubisz 2008, 303).

Jak zauważył J. Kosonoga, czynność ta odnosi się w tym przypadku do wizerunku, dlatego najczęściej będzie ona przejawiała się w fotografowaniu, nagraniu obrazu na taśmie filmowej, kasecie wideo oraz laserowym dysku (Kosonoga 2011, 229). Z kolei M. Mozgawa wraz z K. Nazar-Gutowską podnoszą, iż charakteryzowany czyn to zarejestrowanie określonych treści na odpowiednim nośniku materialnym (Mozgawa, Nazar-Gutowska 2014, 14). Z kolei wedle S. Hypsia utrwalaniem jest czynność stwarzająca możliwość rejestracji określonych treści na właściwym nośniku materialnym, a także nadanie im trwałości, aby można było do niej wrócić w każdym czasie (Hypś 2017, 923). Interesujące podejście do analizowanego 
zagadnienia prezentują M. Królikowski oraz A. Sakowicz (Królikowski, Zawłocki 2017, 609). Otóż utrwalanie obejmuje każdą czynność, która prowadzi do uzyskania przejściowego bądź trwałego obrazu oderwanego od wyglądu lub zachowania się osoby. Koncepcja ta zakłada, iż w zakresie analizowanego terminu mieszczą się również ulotne postacie zachowania konkretnej treści w pamięci nośników (tamże).

J. Kosonoga podaje w wątpliwość, czy utrwalenie dotyczy też werystycznych wizerunków, czy wyłącznie realistycznych. Kryterium rozstrzygające ten problem określa, czy w konkretnej sytuacji mamy do czynienia z wizerunkiem, a także czy istnieje możliwość jego identyfikacji (Kosonoga 2011, 229). R. Krajewski również porusza zagadnienie rozpoznawalności (Krajewski 2012, 26). Wedle przedstawiciela doktryny, aby doszło do wypełnienia znamion przestępstwa z art. 191a k.k., musi nastąpić utrwalenie twarzy osoby, łącznie z innymi częściami jej nagiego ciała (tamże). Jednak może wystąpić sytuacja, w której twarz pokrzywdzonego jest niewidoczna lub jej obraz - niewyraźny. Wówczas inna charakterystyczna cecha ${ }^{4}$ wyglądu może umożliwić rozpoznanie osoby, której wizerunek znajduje się na zdjęciu (Krajewski 2012,26). Należy przyznać słuszność temu poglądowi, bowiem uwzględnia on ratio legis omawianej konstrukcji prawnej przez zapewnienie jak najszerszej ochrony ludzkiej wolności. Winno się też przytoczyć opinię B. Filka, który twierdzi, iż aby uznać, że wizerunek cechuje przymiot rozpoznawalności, nie jest konieczne przedstawienie całej postaci na nośniku materialnym (Filek 2012, 67). Ponadto zdaniem tego autora na etapie stosowania prawa prawdopodobnie identyfikacja będzie najczęściej występowała na podstawie cech statycznych, a w szczególności charakterystycznych rysów osoby, której wizerunek został utrwalony (tamże). Warto dodać, iż wedle M. Królikowskiego wystarczy, aby identyfikacja była możliwa w węższym kręgu odbiorców (Królikowski 2010, 865). Niemniej jednak przedstawiciel doktryny nie sprecyzował semantycznego znaczenia „węższy krąg odbiorców”, aczkolwiek, jak słusznie zauważa B. Filek, można założyć, iż ów wizerunek dla wypełnienia znamion z art. 191a k.k. ma zostać rozpoznany przez więcej niż jedną osobę (Filek 2012, 69). Natomiast J. Kosonoga stoi na stanowisku, że rozpowszechnianie nie musi być powszechne, ponieważ wystarczy, aby utrwalony wizerunek rozpoznały osoby najbliższe pokrzywdzonemu (Kosonoga 2011, 224).

M. Mozgawa oraz K. Nazar-Gutowska zwracają uwagę, że ze względu na semantyczne znaczenie pojęcia „utrwalenie”, jego istota polega na możliwości późniejszego odtworzenia tego, co zostało zarejestrowane (Mozgawa, Nazar-Gutowska 2014, 14). M. Filar uważa, iż utrwalenie wizerunku nagiej osoby może nastąpić przy pomocy dowolnej techniki, aczkolwiek musi ona umożliwiać konfrontację z nim w przyszłości, nawet jeżeli do tej konfrontacji okaże się niezbędny sprzęt techniczny (Filar 2014, 1115). W opinii M. Królikowskiego oraz A. Sakowicza można dopuścić wykładnię znamienia, która zrelatywizuje pojęcie

${ }^{4}$ Na przykład blizna lub tatuaż. 
utrwalania wobec wizerunku z punktu dynamicznego ujęcia (Królikowski, Zawłocki 2017, 609). Stwierdzenie to należy przede wszystkim odnieść do transmisji wizerunku w kontekście usług streamingowych (tamże). Usługi te sprowadzają się do stworzenia możności odbioru obrazu i dźwięku przez użytkowników sieci. Tam z kolei istnieje możliwość czasowego zachowania kopii dla udostępnienia odbioru z określonym przesunięciem czasowym (tamże).

Wyrok Sądu Okręgowego w Jeleniej Górze z dnia 26 lipca 2013 r. (VI Ka 307/13) we fragmencie odnoszącym się do czynności utrwalenia nagiego wizerunku pokrzywdzonej, a także okoliczności popełnienia tego czynu, należy zestawić z przytoczonymi powyżej poglądami przedstawianymi w literaturze przedmiotu. W szczególności warto zwrócić uwagę na znaczenie pojęcia „utrwalanie”, jego cech oraz przymiotu rozpoznawalności wizerunku.

Jednym $\mathrm{z}$ atrybutów, którym winien charakteryzować się wizerunek jako znamię w analizowanym przestępstwie jest rozpoznawalność osoby, której „podobizna" została utrwalona. Co prawda, przymiot ten nie został wyrażony przez ustawodawcę expressis verbis, aczkolwiek, jak zaznaczono we wcześniejszych fragmentach glosy, jego znaczenie jako determinanty dla oceny możności rozpoznania wizerunku podkreślane jest $\mathrm{w}$ doktrynie prawa karnego. W związku z tym na gruncie komentowanego orzeczenia powstają wątpliwości w kwestii: czy oraz w jaki sposób sąd dokonał analizy w przedmiocie identyfikacji wizerunku kobiety. Należy nadmienić, że biegły z zakresu informatyki nie ujawnił w pamięci urządzenia ani zdjęć, ani filmu, którego treści zawierałyby nagi wizerunek V. W. Trzeba też wziąć pod uwagę możliwość, że na skutek drgania rąk sprawcy fotografie lub film są na tyle niewyraźne, iż nie sposób stwierdzić, kogo wizerunek przedstawia. Co więcej, obraz mógł prezentować elementy wyglądu lub cechy anatomiczne, które nie wyróżniały się dostatecznym stopniem rozpoznawalności dla osób trzecich lub najbliższych pokrzywdzonej. Ponadto, jak zauważył Sąd Okręgowy w uzasadnieniu do wyroku, oskarżony twierdził, że utrwalane obrazy mają inny charakter od tego, na który wskazywała kobieta. Oczywiście takie oświadczenie może stanowić element linii obrony wybranej przez M. P., aczkolwiek jest to jedynie przypuszczenie. Dlatego, w opinii autorki glosy, przeprowadzenie analizy co do przedmiotu identyfikacji ,podobizny” osoby, z uwagi na art. 191a k.k., wydaje się co najmniej niepełne, w szczególności mając na względzie brak dostępu do zawartości potencjalnego nośnika informacji.

Natomiast, co się tyczy technicznej strony czynności utrwalania wizerunku, nie można pominąć faktu, iż w przeważającej części doktryny prawa karnego dominuje pogląd, że warunkiem uznania wizerunku za utrwalony jest możliwość jego odtworzenia. W rezultacie musi istnieć nośnik, na którym wspomniany wizerunek został „uwieczniony”. Zwykle ów nośnik będzie przybierał materialną postać, chociażby płótna czy płyty CD. Jednakże na skutek rozwoju technologicznego środek przekazu może występować w formie udostępnienia na serwerze miejsca służącego do przechowywania danych o treściach różnego rodzaju. 
W charakteryzowanym przypadku nie stwierdzono jednak śladów pozostawionych przez sprawcę w następstwie wykonania określonego zdjęcia lub filmu, jak również nie odnaleziono ich zapisanych w pamięci aparatu fotograficznego. W rezultacie uzasadnienie sądu w prezentowanej kwestii można określić mianem polemicznego, gdyż stwierdzenie: „wobec treści wyjaśnień oskarżonego nie można też rozstrzygnąć, czy wykonane zdjęcia i film zostały zapisane w pamięci aparatu, czy jedynie na jego zewnętrznej karcie pamięci, którą oskarżony mógł łatwo usunąć, nie pozostawiając śladu w aparacie" dozwala również na założenie, że dane, np. na skutek błędów w oprogramowaniu urządzenia, nie zostały zapisane, a więc w ogóle nie było możliwości odtworzenia utrwalonego wizerunku. Zatem nie można z całą stanowczością stwierdzić, iż w momencie wykonywania zdjęcia czy filmu został spełniony warunek możności ich odtworzenia.

Ustawodawca w art. 191a k.k. przewidział trzy alternatywne sposoby działania sprawcy: przemoc, groźbę bezprawną oraz podstęp ${ }^{5}$. Nie jest wymagane, aby którekolwiek z wymienionych zachowań nastąpiło równocześnie z utrwalaniem nagiego wizerunku (Mozgawa 2016, 526). Wedle T. Hanuska przemoc należy pojmować jako odziaływanie takiego rodzaju środkami fizycznymi, które służą uniemożliwieniu lub przełamaniu oporu zmuszanej osoby (Hanusek 1966, 65). W rezultacie działanie to ma na celu albo nie dopuścić do powstania lub wykonania decyzji woli, albo - poprzez naciskanie aktualnie wyrządzaną dolegliwością - nastawić na procesy motywacyjne, ukierunkować decyzję pokrzywdzonego zgodnie z wolą sprawcy (tamże). Z kolei za groźbę bezprawną w rozumieniu tej regulacji winno poczytywać się zarówno groźbę ujętą w art. 190 k.k., jak i groźbę spowodowania postępowania karnego lub rozgłoszenia wiadomości uwłaczającej czci zagrożonego lub jego osoby najbliższej. Jednocześnie nie stanowi groźby zapowiedź spowodowania postępowania karnego ${ }^{6}$. Należy zauważyć, iż alternatywne sposoby działania rozbójniczego mają zostać bezpośrednio skierowane w stosunku do pokrzywdzonego, a więc wyklucza to możliwość zakwalifikowania określonego czynu jako wypełniającego znamiona przestępstwa, jeżeli przemoc, groźba bezprawna lub podstęp były skierowane wobec osoby trzeciej.

Przenosząc powyższe definicje na grunt komentowanego stanu faktycznego, należy stwierdzić, że zachowanie oskarżonego wobec V. W. mieściło się w zakresie desygnatów pojęcia „przemoc”, gdyż dopuścił się on względem kobiety czynu w postaci włożenia jej głowy do sedesu, uderzeń w twarz i kopania po całym ciele. Trafnie wskazuje się orzecznictwie, iż szeroka wykładnia znamienia „przemoc wobec osoby” umożliwia objęcie nim takich zachowań, które naruszają nietykalność cielesną. Jednakże mogą być one uznane za wyczerpujące znamiona, jeżeli stanowiły czynnik wpływający na sferę wolicjonalną pokrzywdzonego, jak

${ }^{5}$ Ze względu na treść stanu faktycznego glosowanego orzeczenia, omówienie sposobu działania sprawcy zostanie ograniczone do przemocy oraz groźby bezprawnej.

${ }^{6}$ Zob. art. $115 \S 12$ k.k. 
również miały istotnie większy od minimalnego stopień intensywności i dolegliwości względem tej osoby (IV KK 188/05). W rezultacie można założyć, że działania wymierzone przez M. P. stanowiły co najmniej naruszenie nietykalności cielesnej pokrzywdzonej ${ }^{7}$. Podjęte przez oskarżonego działania z pewnością spełniały wymóg dotyczący intensywności dolegliwości doznanej przez V. W.

Z kolei znamię skierowania ,groźby bezprawnej” względem pokrzywdzonej zostało wypełnione w momencie przymuszenia kobiety do napisania listu pożegnalnego, a także zapowiedzią pozbawienia jej życia. Należy zaznaczyć, iż w przypadku groźby bezprawnej z art. $115 \S 12$ k.k. nie musi być ona wyrażona wprost. Ustawodawca dopuszcza tzw. zachowania konkludentne, czyli takie, przez które pokrzywdzony poczuje się zagrożony (Dąbrowska-Kardas, Kardas 2008, 118). Jak zaznacza M. Dąbrowska-Kardas oraz P. Kardas, o tzw. groźbie konkludentnej można mówić wtedy, gdy po przeprowadzeniu szczegółowej analizy zachowania sprawcy, w świetle określonych okoliczności zdarzenia, należy stwierdzić, że sprawca jest gotów użyć przemocy wobec osoby, gdyby ta nie podporządkowała się jego żądaniu (tamże). Fakt, iż M. P. na kilka dni pozbawił kobietę wolności, a także był uprzednio skazany za przestępstwo z art. $204 \S 1$ k.k., nie pozostawia wątpliwości, iż czynności w postaci spisania listu pożegnalnego przez kobietę oraz grożenie jej pozbawieniem życia mogły u pokrzywdzonej wzbudzać uzasadnioną obawę ziszczenia treści groźby.

Nie można całkowicie pominąc doniosłości wyjaśnień oskarżonego czy zeznań pokrzywdzonej w kontekście dowodu. Zważywszy na całokształt wydarzeń towarzyszących opisywanemu czynowi, można przypuszczać, iż perspektywa występowania zaburzeń psychicznych u tego sprawcy jest niewielka. M. P. przyznał się do utrwalenia nagiego wizerunku pokrzywdzonej, co czyni prawdopodobną możliwość popełnienia przez niego przestępstwa. W rezultacie wydaje się, że zachowanie oskarżonego przyjmuje postać działania w zamiarze popełnienia czynu zabronionego oraz bezpośredniego zmierzania do jego dokonania (zob. wyrok SA w Białymstoku z dnia 21 stycznia 2014 r., II AKa 259/13, LEX nr 1496372). Bezpośrednie zmierzanie do dokonania czynu następuje, gdy sprawca przystępuje do ostatniej czynności, która ma doprowadzić do realizacji powziętego czynu. Należy uznać, że zachowanie sprawcy bezpośrednio zmierza do popełnienia przestępstwa, jeżeli zagrożenie względem dobra prawnego, które stanowi znamię czynu zabronionego objętego zamiarem sprawcy, ulega przeobrażeniu z zagrożenia abstrakcyjnego w realne (II KK 322/06). Nie ulega wątpliwości, iż czynności podjęte przez M. P. zmierzały bezpośrednio do wypełnienia znamion w ramach art. 191a k.k. Wykonywanie następujących kolejno po sobie działań względem pokrzywdzonej z góry przesądza o zamiarze powziętym przez oskarżonego. Z kolei fakt, iż sąd zdecydował o konieczności powołania biegłego z zakresu informatyki do

${ }^{7}$ Nie można wykluczyć, iż zachowanie sprawcy, ze względu na wzmożoną intensywność wykraczało poza zakres pojęcia „naruszenia nietykalności cielesnej”. 
poczynienia ustaleń $\mathrm{w}$ przedmiocie zapisu utrwalonego nagiego wizerunku w pamięci aparatu, świadczy o realnym zagrożeniu dla prawa do swobodnego dysponowania nagim wizerunkiem w kontekście dobra prawnego. Wobec powyższych stwierdzeń wydaje się, że warto rozważyć kwalifikację działań oskarżonego na podstawie art. 191a k.k. w zw. z art. 13 k.k.. Okoliczności charakteryzowanego stanu faktycznego pozwalają na stwierdzenie, iż mężczyzna przynajmniej usiłował wypełnić znamiona czynu zabronionego własnym zachowaniem. Szereg przedsięwziętych przez niego czynności sprawia, iż przestępstwo mogło przybrać formę zarówno usiłowania udolnego, jak i nieudolnego. Pierwsze z nich nastąpiłoby wówczas, gdyby M. P. utrwalił wizerunek nagiej pokrzywdzonej za pomocą aparatu fotograficznego, lecz podczas tej czynności drżałaby mu ręka. Wskutek tego potencjalny wizerunek nie cechowałby przymiot rozpoznawalności (zob. art. $13 \S 1$ k.k.). Z kolei drugi rodzaj usiłowania zachodziłby w przypadku niemożności odtworzenia zdjęć lub filmu na skutek błędu w oprogramowaniu, które obsługuje urządzenie rejestrujące (zob. art. 13 § 2 k.k.). Co więcej, taki sam rodzaj formy stadialnej można przypisać czynowi, jeżeli w aparacie nie została umieszczona karta pamięci lub byłaby ona przepełniona. Wówczas w urządzeniu powinna pojawić się informacja odnosząca się np. do braku karty lub jej przepełnienia. Fotografia nie zostanie zapisana na karcie, lecz sam ostatni obraz tymczasowo jest „utrwalany” w pamięci aparatu i można go zobaczyć na podglądzie do czasu wyłączenia sprzętu. Warto zwrócić uwagę, iż wymiar kary za usiłowanie na podstawie art. 14 k.k. kształtuje się w granicach ustawowego zagrożenia przewidzianego dla dokonania określonego przestępstwa, aczkolwiek jeżeli zachowanie oskarżonego uznano by za usiłowanie nieudolne, wówczas w gestii sądu pozostaje ewentualne złagodzenie jej wymiaru (zob. art. 14 § 2 k.k.). Dlatego brak przekonania co do formy popełnienia przestępstwa w przedmiocie, czy doszło do dokonania, czy jedynie do usiłowania, nie będzie w każdym przypadku decydował o wysokości kary dla skazanego ${ }^{8}$. Przedstawione argumenty, a w szczególności brak możliwości odtworzenia potencjalnie utrwalonego nagiego wizerunku V. W. skłaniają do rozpatrywania podjętych przez sprawcę działań w kontekście usiłowania.

Podsumowując wyrok Sądu Okręgowego w Jeleniej Górze z dnia 26 lipca 2013 r. (VI Ka 307/13) w części związanej z czynnością utrwalania nagiego wizerunku, nie sposób nie wspomnieć o zawartych tam trafnych spostrzeżeniach, jak i o pewnych nieścisłościach. Na aprobatę zasługuje rozpatrywanie czynu, którego dopuścił się M. P. z uwagi na art. 191a k.k. Całokształt zachowania sprawcy, przedstawiony w orzeczeniu, pozwala na jednoznaczne stwierdzenie, iż podjęte przez niego działania były nastawione na zamach względem prawa do intymności, które to stanowi element godności ludzkiej. W analizowanym zagadnieniu

${ }^{8}$ Jednakże na wysokość orzeczonej kary wpływa stopień społecznej szkodliwości czynu, który często jest określany na niższym poziomie w przypadku usiłowania aniżeli dokonania przestępstwa. 
nie występuje czyn o charakterze seksualnym sensu stricto. Mimo iż przedmiot czynności wykonawczej stanowi nagi wizerunek kobiety, dobro prawne w postaci wolności seksualnej może występować jedynie jako uboczny przedmiot ochrony. Należy także pozytywnie ocenić rozpoznanie tzw. znamion rozbójniczych, bowiem co do ich zaistnienia nie ma wątpliwości.

Natomiast niektóre z elementów rozumowania dokonanego przez Sąd Okręgowy mogą budzić wątpliwości. Mianowicie, skoro nie można stwierdzić, czy zdjęcia oraz film zostały zapisane w pamięci aparatu, czy też na karcie zewnętrznej, nie jest również możliwe określenie, czy wspomniane obrazy były zdatne do ich odtworzenia. W dodatku brak możności weryfikacji w zakresie rozpoznawalności wizerunku pokrzywdzonej, a także sprzeczna ocena oskarżonego i pokrzywdzonej co do charakteru utrwalonego wizerunku sprawiają, iż powstaje pytanie o realizację wszystkich ustawowych znamion czynu zabronionego z art. 191a k.k. Wydaje się, iż zeznania kobiety oraz wyjaśnienia sprawcy są niewystarczające, by z całą pewnością stwierdzić, iż zostały przytoczone wszelkie faktyczne okoliczności popełnienia czynu. Co więcej, z uwagi na brak posiadanej przez sąd wiedzy na temat możliwości odtworzenia wizerunku, tj. jednego z założeń czynności utrwalania, należy rozważyć słuszność kwalifikacji analizowanego czynu jako dokonania przestępstwa.

\section{BIBLIOGRAFIA}

Berent, Marcin, Filar, Marian. 2016. „Art. 191a k.k. Rozdział XXIII. Przestępstwa przeciwko wolności”. W Kodeks karny. Komentarz. Red. Marian Filar. Warszawa: Wolters Kluwer.

Dąbrowska-Kardas, Małgorzata, Piotr Kardas. 2008. „Art. 190 k.k. Rozdział XXIII. Przestępstwa przeciwko wolności”. W Kodeks karny. Część szczególna. Komentarz do art. 117-277 k.k. T. II. Red. Andrzej Zoll. Warszawa: Wolters Kluwer.

Dubisz, Stanisław (red.). 2008. Uniwersalny słownik języka polskiego PWN. Warszawa: Wydawnictwo Naukowe PWN.

Filar, Marian. 2014. „Art. 191a k.k. Rozdział XXIII. Przestępstwa przeciwko wolności”. W Kodeks karny. Komentarz. Red. Marian Filar. Warszawa: Wolters Kluwer.

Filek, Bartłomiej. 2012. „Wizerunek nagiej osoby jako znamię przestępstwa z art. 191a $§ 1$ k.k.”. Prokuratura i Prawo 7-8: 61-77.

Hanusek, Tadeusz. 1966. Przemoc jako forma działania przestępnego. Kraków: Uniwersytet Jagielloński.

Hypś, Sławomir. 2017. „Art. 191a k.k. Rozdział XXIII. Przestępstwa przeciwko wolności”. W Kodeks karny. Komentarz. Red. Alicja Grześkowiak, Krzysztof Wiak. Warszawa: C.H. Beck.

Kosonoga, Jacek. 2011. „Karnoprawna ochrona intymnego wizerunku”. W Studia i analizy Sadu Najwyższego. T. V. Red. Krzysztof Ślebzak. Warszawa: Wolters Kluwer.

Kosonoga, Jacek. 2017. „Art. 191a k.k. Rozdział XXIII. Przestępstwa przeciwko wolności”. W Kodeks karny. Komentarz. Red. Ryszard A. Stefański. Warszawa: C.H. Beck.

Krajewski, Radosław. 2012. „Przestępstwo utrwalania i rozpowszechniania wizerunku nagiej osoby lub osoby w trakcie czynności seksualnej”. Prokuratura i Prawo 5: 20-40. 
Królikowski, Michał. 2010. „Art. 191a k.k. Rozdział XXIII. Przestępstwa przeciwko wolności”. W Kodeks karny. Komentarz do art. 117 do 221. Red. Andrzej Wąsek, Robert Zawłocki. Warszawa: C.H. Beck.

Królikowski, Michał, Robert Zawłocki. 2017. „Art. 191a k.k. Rozdział XXIII. Przestępstwa przeciwko wolności”. W Kodeks karny. Komentarz. Red. Michał Królikowski, Robert Zawłocki. Warszawa: C.H. Beck.

Lachowski, Jerzy. 2016. „Art. 191a k.k. Rozdział XXIII. Przestępstwa przeciwko wolności”. W Kodeks karny. Komentarz. Red. Violetta Konarska-Wrzosek. Warszawa: Wolters Kluwer.

Mozgawa, Marek. 2016. „Rozdział II. Przestępstwa przeciwko wolności”. W Przestępstwa przeciwko dobrom indywidualnym. T. 10. Red. Jarosław Warylewski, Warszawa: C.H. Beck.

Mozgawa, Marek. 2017. „Art. 191a k.k. Rozdział XXIII. Przestępstwa przeciwko wolności”. W Kodeks karny. Komentarz. Red. Marek Mozgawa. Warszawa: Wolters Kluwer.

Mozgawa, Marek, Katarzyna Nazar-Gutowska. 2014. „Utrwalanie lub rozpowszechnianie wizerunku nagiej osoby - art. 191a k.k. (analiza prawnokarna i praktyka ścigania)". Prawo w Działaniu-Sprawy Karne 19: 7-40.

\title{
Akty prawne
}

Ustawa z dnia 6 czerwca 1997 r. - Kodeks karny (Dz. U. 1997, Nr 88, poz. 553 ze zm.).

Ustawa z dnia 6 czerwca 1997 r. - Kodeks postępowania karnego (Dz. U. 1997, Nr 89, poz. 555 ze zm.).

Ustawa z dnia 29 lipca 2005 r. o przeciwdziałaniu narkomanii (Dz. U. 2005, Nr 179, poz. 1485 ze zm.).

Ustawa z dnia 5 listopada 2009 r. o zmianie ustawy - Kodeks karny, ustawy - Kodeks postępowania karnego, ustawy - Kodeks karny wykonawczy, ustawy - Kodeks karny skarbowy oraz niektórych innych ustaw (Dz. U. 2009, Nr 206, poz. 1589).

\section{Orzecznictwo}

Postanowienie SN, Izba Karna z dnia 6 lipca 2005 r., sygn. IV KK 188/05, OSNwSK, poz. 1328. Wyrok SN, Izba Karna z dnia 4 września 2007 r., II KK 322/06, OSNwSK 2007, poz. 1964.

Wyrok Sądu Okręgowego w Jeleniej Górze z dnia 26 lipca 2013 r. http://orzeczenia.ms.gov.pl/content/ wizerunek/155005000003006_VI_Ka_000307_2013_Uz_2013-07-26_002 [dostęp 12.01.2018].

\section{Karolina Witczak}

\section{COMMENTARY ON THE SENTENCE OF THE REGIONAL COURT - JULY 26, 2013, REF. NO. VI KA 307/13}

\begin{abstract}
The article refers to the offence of fixation of the image of the naked person. The author tried to consider the issue of a possibility of image recognition when there was no information medium on which the image should be saved. In addition, the problem of significance of right to intimacy under art. 191a of the Penal Code was discussed. The act of playing of the image as a requirement to realize the feature of "fixation of the image" was also worth noting. Furthermore, the features of "violence" and "threat" were analyzed due to the type of resources used by the perpetrator to commit this offence. Finally, the matter of qualifying this act as an attempt to commit an offence was raised.
\end{abstract}

Keywords: fixation of the image, image of naked person, offences against freedom, right to intimacy, attempt to fix of the image of naked person. 